progestogen therapy administered singly, but the available evidence indicates that the oestrogen component alone can account for the abnormalities of glucose tolerance (Javier et al., 1968; Goldman et al., 1968; Goldman and Ovadia, 1969) and blood pyruvate levels (Doar et al., 1969) during combined

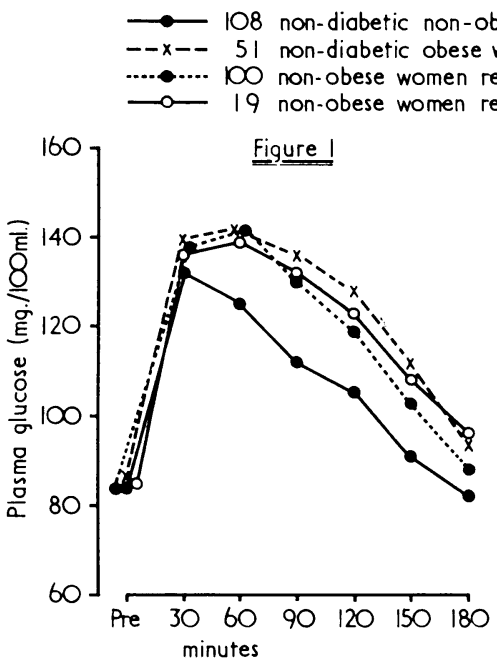

se women

receiving oral contraceptive theropy

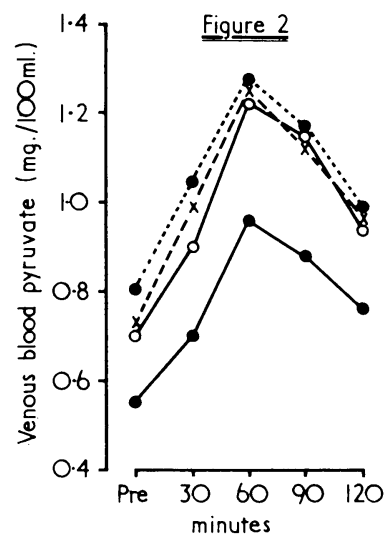

Fig. 1.-Mean O.G.T.T. plasma glucose levels. Fig. 2-Mean O.G.T.T. venous blood pyruvate level.

oestrogen-progestogen therapy. Circulating plasma cortisol levels are usually normal in obesity, but the cortisol production rate is often increased (Schteingart and Conn, 1965). The hepatic clearance of cortisol is therefore increased and a local effect on hepatic glucose and pyruvate handling is possible.

Obesity (Perley and Kipnis, 1966a), oral contraceptive therapy (Wynn and Doar, 1969), and glucocorticoid therapy (Perley and Kipnis, 1966b) are associated with raised plasma insulin levels in response to a glucose tolerance test. Since plasma glucose levels are also increased, it appears that there is increased resistance in one or more tissues to the actions of insulin. Studies of pyruvate metabolism using a sodium $\mathrm{L}$ $(+)$ lactate infusion technique have suggested that the abnormally raised blood pyruvate levels in obesity, and during glucocorticoid or oral contraceptive therapy, are caused by an increased proportion of the glucose load passing down the glycolytic pathway to pyruvate rather than an impaired rate of removal of this metabolite (Doar et al., 1969; Doar and Cramp, in preparation). If the peripheral insulin resistance referred to above were to affect non-glycolytic pathways of glucose metabolism more than the glycolytic pathway, the combination of raised plasma glucose and insulin levels could result in an increased rate of formation of pyruvate from glucose in certain tissues.

The increased variance of blood pyruvate levels in response to a glucose tolerance test in the non-obese oral contraceptive and glucocorticoid groups may reflect the heterogeneous nature of the drug therapy. The type of drug and dose and duration of therapy varied widely within each group. We have been unable to detect, however, a relation between any one of these factors and the change of blood pyruvate levels during oral contraceptive therapy (Doar et al., 1969). The increased variance in the control obese group may be due to the greater range of degree of obesity of these subjects compared with that of the non-obese group, since we have previously found a significant correlation $(\mathrm{r}=0.32, \mathrm{P}<0.01)$ between the fasting blood pyruvate level and the degree of obesity in non-diabetic women (Doar et al., 1968).

The abnormalities of blood pyruvate levels in response to a glucose tolerance test reported here differ from those observed in maturity-onset diabetes mellitus. In a detailed study (Doar et al., in preparation) we have found no influence of diabetes mellitus (either maturity-onset or insulin-requiring) on the fasting blood pyruvate level. The mean fasting blood pyruvate level, however, was higher in obese than non-obese diabetic subjects. Mean blood pyruvate levels were higher in both obese and non-obese maturity-onset diabetic subjects during the later stages of the test compared with mean blood pyruvate levels in non-diabetic subjects of similar degree of obesity.

This work was supported in part by contract No. Ph-43-67-1344 from the National Institute of Health, Bethesda, Md., U.S.A.

\section{REFERENCES}

Burke, C. W. (1969). British Medical fournal. 2, 798.

Cramp, D. G. (1967). Fournal of Clinical Pathology, 20, 910.

Cramp, D. G. (1968). Fournal of Clinical Pathology, 21, 171.

Doar, J. W. H., Wynn, V., and Cramp, D. G. (1968). Metabolism, 17, 690.

Doar, J. W. H., Wynn, V., and Cramp, D. G. (1969). In Metabolic Effects of Gonadal Hormones and Contraceptive Steroids (edited by H. A. Salhanick, D. M. Kipnis, and R. L. Vande Wiele, p. 178). New York, Plenum Press.

Gershberg, H., Javier, Z., and Hulse, M. (1964). Diabetes, 13, 378

Goldman, J. A., and Ovadia, J. L. (1969). American fournal of Obstetrics and Gynecology, 103, 172 .

Goldman, J. A., Ovadia, J. L., and Eckerling, B. (1968). Israel fournal of Medical Sciences, 4, 878.

Javier, Z., Gershberg, H., and Hulse, M. (1968). Metabolism, 17, 443.

Keller, N., Richardson, U. I., and Yates, F. E. (1969). Endocrinology, 84, 49.

Matsui, N., and Plager, J. E. (1966). Endocrinology, 78, 1159.

Perley, M., and Kipnis, D. M. (1966a). Diabetes, 15, 867.

Perley, M., and Kipnis, D. M. (1966b). New England fournal of Medicine, $274,1237$.

Posner, N. A., Silverstone, F. A., Pomerance, W., and Baumgold, D. (1967a). Obstetrics and Gynecology, 29,79.

Posner, N. A., Silverstone, F. A., Pomerance, W., and Singer, N. (1967b). Obstetrics and Gynecology, 29, 87.

Sandberg, A. A., Rosenthal, H. E., and Slaunwhite, W. R., jun. (1969). In Metabolic Effects of Gonadal Hormones and Contraceptive Steroids, edited by H. A. Salhanick, D. M. Kipnis, and R. L. Vande Wiele, p. 367. New York, Plenum Press.

Schteingart, D. E., and Conn, J. W. (1965). Annals of the New York Academy of Sciences, 131, 388.

Wynn, V., and Doar, J. W. H. (1966), Lancet, 2, 715.

Wynn, V., and Doar, J. W. H. (1969). In Metabolic Effects of Gonadal Hormones and Contraceptive Steroids, edited by H. A. Salhanick, D. M. Kipnis, and R. L. Vande Wicle, p. 219. New York, Plenum Press.

\title{
Contraception with Chlormadinone Acetate in Woman with Previous Contraceptive Jaundice
}

\author{
R. P. H. THOMPSON, ${ }^{*}$ B.M., M.R.C.P.; ROGER WILLIAMS, $†$ M.D., F.R.C.P.
}

$S^{n}$ had developed jaundice during four pregnancies, and twice while taking a combined contraceptive pill. No side-effects or changes in liver function were observed. This is further evidence that progestogens used for contraception, and in particular those derived from hydroxyprogesterone, are less hepatotoxic than the oestrogenic components.

\section{Introduction}

About a third of the women who develop jaundice while taking a contraceptive pill have previously had itching or choles-

* M.R.C. Clinical Research Fellow.

† Consultant Physician and Director, Medical Research Council Group on Metabolism and Haemodynamics of Liver Disease, King's College Hospital, London S.E.5. 
tatic jaundice during pregnancy (Óckner and Davidson, 1967). The latter is thought to be due to susceptibility to the high level of circulating oestrogens. All the combined contraceptive preparations which contain both oestrogen and progestogen have been incriminated in individual case reports. In this paper we describe the use of the progestogen chlormadinone acetate alone in a woman with a previous history of recurrent jaundice, both when pregnant and while on a combined pill.

\section{Case History}

In 1964 a 24-year-old Nigerian woman became pregnant for the first time, and was delivered of a normal baby at 37 weeks. Towards the end of the first trimester itching, dark urine, and jaundice were noticed, and by the ninth month the serum bilirubin was $4.5 \mathrm{mg} . / 100 \mathrm{ml}$., alkaline phosphatase $29 \mathrm{King}$-Armstrong (K.A.) units $/ 100 \mathrm{ml}$., and alanine aminotransferase 19 i.u. $/ \mathrm{ml}$. The symptoms regressed after delivery. In March 1967 her second pregnancy ended in an abortion at three months, though by this time itching and jaundice had already developed. In October 1967 she had a normal delivery at 33 weeks, again suffering from itching and jaundice throughout most of the pregnancy. Soon after delivery she started on the contraceptive pill and for the first time her symptoms persisted beyond the puerperium. When she stopped the pill three months later the symptoms promptly regressed.

In February 1968 she was admitted to King's College Hospital for assessment. Physical examination was normal and the plasma bilirubin was $0.9 \mathrm{mg} . / 100 \mathrm{ml}$. The histology of an aspiration needle liver biopsy specimen was normal.

She remained well for eight months, but in October she started on Ortho-novin $2 \mathrm{mg}$. (norethisterone and mestranol). One week later itching and dark urine were noticed, and she stopped the pill after three weeks. Soon after this she became pregnant for the fourth time, and was readmitted with severe itching. The plasma bilirubin was $1.2 \mathrm{mg} . / 100 \mathrm{ml}$., partly conjugated, serum alkaline phosphatase $20 \mathrm{~K}$.A. units $/ 100 \mathrm{ml}$., and aspartate aminotransferase 33 i.u. $/ \mathrm{ml}$. Serum bile acids were raised. The plasma clearance of bromsulphthalein showed a secondary rise in blood level at one to two hours after injection, consistent with regurgitation of conjugated bromsulphthalein into the blood. In January 1969 a therapeutic abortion was performed and, subsequently, liver function tests showed improvement.

She preferred oral to mechanical contraception, and in February 1969 was started on continuous chlormadinone acetate, 0.5 mg./day. She has remained well since, during eleven months treatment. Liver function tests and the serum cholic acid were normal, and a repeat bromsulphthalein test showed a normal clearance.

\section{Discussion}

The cause of the jaundice of pregnancy (Haemmerli, 1966), or of that due to the combined oestrogen-progestogen contraceptive pill (Thompson and Williams, 1969), is not known, though there is some evidence that oestrogens are responsible. Oestriol may alter the permeability of the biliary tree and reduce bile flow in rats (Forker, 1969). In normal women oestradiol (Mueller and Kappas, 1964; Kottra and Kappas, 1966) and stilboestrol (Clinch and Tindall, 1969) increase the retention of bromsulphthalein. Further, $17 \alpha$-ethynyloestradiol and mestranol have been shown to cause symptoms and impair liver function tests when given to women with a history of jaundice of pregnancy (Kreek et al., 1967; Urban et al. 1968). These results suggest that a few susceptible women react abnormally to the oestrogens of the contraceptive pill or to those circulating during pregnancy.

Some of the progestogens used for contraception may increase the hepatotoxicity of oestrogens. Thus Eisalo et al. (1968) found that the oestrogen mestranol and progestogen lynoestrenol together were more hepatotoxic in postmenopausal women than was mestranol alone. The 19norprogestogens, which are partly metabolized to the potentially hepatotoxic $17 \alpha$-ethynyloestradiol (Brown and Blair, 1960), can occasionally cause jaundice when given without an oestrogen (Somayaji et al., 1968). The progestogens megestrol and chlormadinone, which are derivatives of hydroxyprogesterone, are not so metabolized (Cooper and Kellie, 1968) and have not so far been implicated in contraceptive jaundice. In 10 postmenopausal women the 19-norprogestogen lynoestrenol impaired tests of liver function, while megestrol acetate did not (Eisalo et al., 1968); nor did it impair the plasma clearance of bromsulphthalein in 21 puerperal women (Clinch and Tindall, 1969).

Contraception with hydroxyprogesterone progestogens alone should therefore be less hepatotoxic than the combined preparations. The present patient gives a history of recurrent itching and jaundice during four pregnancies and two courses of the combined contraceptive pill. If chlormadinone were hepatotoxic, this woman should certainly have reacted to it.

Chlormadinone alone produces fewer symptoms, with less risk of thrombosis (Butler and Hill, 1969), than have the combined preparations. It is, however, a less effective contraceptive (Howard et al., 1969). Nevertheless, at the moment chlormadinone would appear to be the best available preparation for those few women who give a previous history of pruritus or jaundice of pregnancy or of hepatic susceptibility to the contraceptive pill.

We are grateful to Dr. D. A. Pyke and Mr. M. Brudenell for their help, to Dr. M. A. Eastwood for measuring serum bile acids, and to Imperial Chemical Industries for the supply of chlormadinone.

\section{REFERENCES}

Brown, J. B., and Blair, H. A. F. (1960). Proceedings of the Royal Society of Medicine, 53,433 .

Butler, C., and Hill, H. (1969). Lancet, 1, 1116.

Butler, C., and Hill, H. (1969). Lancet, 1, 1116. Clinch, J., and Tindall, V. R. (1969). British Medical fou

Eisalo, A., Heino, A., and Räsänen, V. (1968). Acta Obstetricia et Gynecologica Scandinavica, 47, 58.

Forker, E. L. (1969). Fournal of Clinical Investigation, 48, 654.

Haemmerli, U. P. (1966). Acta Medica Scandinavica, 179, Suppl. No. 444.

Howard, G., Elstein, M., Blair, M., and Morris, N. F. (1969). Lancet, 2,24 .

Kottra, L. L., and Kappas, A. (1966). Archives of Internal Medicine, $117,373$.

Kreek, M. J., Weser, E., Sleisenger, M. H., and Jeffries, G. H. (1967). New England Fournal of Medicine, 277, 1391

Muller, M. N., and Kappas, A. (1964). Fournal of Clinical Investigation, 43, 1905 .

Ockner, R K., and Davidson, C. S. (1967). New England fournal of Medicine, 276, 331 .

Somayaji, B. N., Paton, A., Price, J. H., Harris, A. W., and Flewett, T. H. (1968). British Medical fournal, 2, 281

Thompson, R P. H., and Williams, R. (1969). Postgraduate Medical

Fournal, 45, 196.
Urban, E., Frank., B. W., and Kern, F. (1968). Annals of Internal Medicine, 68, 598 . 